\title{
Transforming Society through Quality Primary Education in South Africa: Lessons from Two Decades after Apartheid
}

\author{
Vuyisile Msila \\ PO Box 392, College of Education, University of South Africa, UNISA, 0003, South Africa \\ msilavt@unisa.ac.za
}

Doi:10.5901/mjss.2014.v5n6p339

\begin{abstract}
All families would like to see their children attain success through formal education. The child is also under pressure to learn culture, discipline and morality. Effective education is seen by many as an act that not only should help build the children through these societal values but also expects the children to learn from the demands of a constantly changing globalising world. There is however, much need to review primary education as well as methods used to teach children. This paper explores the challenges faced by many historically disadvantaged schools in South Africa and why it has become insurmountable to improve learner achievement. Many learners who start primary school encounter many challenges in underresourced schools and a few drop out before high school. Some critics aver that the apartheid legacy in South Africa still looms large and is thwarting some of the progress that would have been made. Furthermore, the paper explores the poor performance in the national assessment of learners examining aspects such as social and cultural capital. The presentation concludes by focusing on strategies that can be implemented to improve learner achievement and these include enhancing school management, improving teacher education programs and developing poor and under-resourced schools.
\end{abstract}

Keywords: Primary school challenges. Apartheid education. School improvement. Literacy and numeracy. Quality schools.

\section{Introduction and Background}

Early Childhood Development (ECD) education in South Africa is perceived as a basis of laying a good foundation for children from birth to 9 years old. The White Paper 5 (2001) points out that "Early Childhood Development refers to a comprehensive approach to policies and programs for children from birth to nine years of age with the active participation of their parents and caregivers. Its purpose is to protect the child's rights to develop his or her full cognitive, emotional, social and physical potential." Furthermore, the ECD policy as espoused in the White Paper seeks to ensure that South Africa invests in ECD because it has been proven that early influences of the first few years have an impact on the rest of the child's life. It has also been proven that, "intervening in the earliest years helps to reduce the social and economic disparities and race and gender inequalities that divide our societies" (White Paper 5). Schooling for example, needs to make a difference or else it would amount to what Bourdieu refers to as social reproduction.

The post-apartheid policy also seeks to create opportunities for all children and their families. Whilst apartheid policy was outlawed with the advent of the democratic rule in 1994, its effects still loom large. The historically black African schools have the lowest quality of education. Evoh and Mafu (2007) aptly put it when they argue that South Africa is faced by two challenges: (i) to address the backlog of basic educational needs of millions of people who were denied education at the right age in the past; and (ii) meet the increasing demands for basic education of the present generation of children who are at the right age for such level of education. Much has been done to redress apartheid imbalances. Yet other challenges have surfaced over the past two decades. The country is not producing enough teachers. South Africa produces about 6000 teachers annually (OECD, 2013). This is way too low for the replacement need of approximately 20 000 teachers. The OECD document points out that the situation is aggravated by the fact that, " about fourth of newly qualified teachers, especially white teachers, plan to leave the country to teach abroad, and about half of new teachers have recently considered leaving the profession" (OECD 2013:68).

This paper explores some of the challenges to the provision of effective childhood education in South Africa. The ensuing discussions look at review of literature, equal opportunity and lifelong learning, the implications of the annual national assessment results. Finally, the focus is on what needs to be done to improve the quality of early childhood education. 


\section{Review of Literature}

Taguma, Litjens and Makowiecki (2013) argue how early childhood education has become a priority in many countries around the world. Furthermore, these authors underscore the need for a curriculum practice in which cognitive and social development are viewed as complementary; such curriculum is believed to improve social behaviour as it presents high quality ECD. Taguma et al (2013) also point out that literacy; numeracy and ICT are among the most crucial learning areas for ECD. The Frank Porter Graham (FPG) Child Development Institute (2013) concurs with the above arguments and they add that the value of high quality early childhood education is the key to any country's future and that early childhood teacher preparation programs should be capable of preparing the $21^{\text {st }}$ century educators. One of the challenges that teachers have to deal with in the primary schools is to ensure that they sustain education that would curb or protect drop-out from formal education all over the world (Haque, Nasrin, Yesmin \& Biswas, 2013).

Strickland and Riley-Ayers (2006) highlight a number of important issues concerning early childhood education. Among these are strong home-school connections where they argue that supportive parental involvement enhances early literacy development. These authors state how oral language is the foundation for literacy development and that learning to read and write starts long before first grade and has long lasting effects. These authors contend:

Studies of the relationship between early literacy development and school achievement have had a profound impact on the early literacy curriculum as an intervention process for children considered to be at risk for failure. Risk factors include exhibiting a developmental disability (e.g. oral language impairment, mental retardation, hearing impairment), having a parent with a history of a ready disability, speaking a language or...

The Education for All Global Monitoring Report (EFA GMR) (2013) shows that the progress in reducing children out of school has come to a stop as international aid to basic education has fallen since 2002. This report further explicates that about 250 million primary-school aged children have not learnt the basics "whether they are in school or not." The EFA GMR Report (2013:1) spells out the international crisis in childhood education:

Early grade reading assessments in several countries have shown that many children spend two or three years in school without learning to read a single word. In Mali, for instance, $94 \%$ of second graders could not read a single word in French and at least eight out of ten could not read a single word in four national languages, despite the fact that Mali is the most advanced among West African Francophone countries in using national languages in education.

Similar results were found in northern Nigeria where the majority of grade 3 learners assessed in Hausa could not read full words. The teacher quality was found to be critical because in some similar countries (in terms of economy), learner performance was better because teachers were more skilled in the subjects they teach. The OECD (2013) survey in South Africa also perceived teacher quality as pertinent. "Teachers' knowledge of the subjects they teach has been questioned in both regional tests (SACMEQ, 2007) and national survey (Taylor et al, 2012). Moreover, South Africa is confronted with a marked teacher shortage" (OECD 2013:67).

All countries need to invest in their children. Yet more countries still need to be sensitised in prioritising early childhood in their health, education, poverty reduction or other national plans and many countries lack early childhood development policies, strategic plans and laws (CGECCD, 2013). The Millennium Development Goals (MDGs) underscore universal primary education stressing the need for children to be able to complete primary schooling by 2015. The three indicators linked to these are; Firstly the net enrolment ratio in primary education, secondly the proportion of pupils starting grade 1 who reach last grade of primary school and finally, literacy rate of 1524 year old women and men. Unterhalter (2013) cites the Convention of the Rights of the Child (CRC) who advocate for children's rights. This author points out that CRC supports the children's protection from violence as well as support for identity formation (Unterhalter, 2013). Despite such initiatives which are introduced in various parts of the world, a number of counties have varying challenges when it comes to children and primary education.

\section{South African Children in School: Two Futures?}

Equity, access and success in schools are influenced by the socio-economic status of the children's families. A few authors have written about that state of primary school education in South Africa. Brahm Fleisch (2008) for example, writes about how the society concentrates on improving secondary school results and neglect the primary school education. Fleisch also highlights the dropping standards in primary school literacy and numeracy in South Africa 
touching upon various reasons that lead to this. Taylor, Fleisch and Shindler (2007) argue about the need for long-term planning and focus on primary school literacy and mathematics. These authors point out that this is an urgent problem. Spaull (2012) declares how South Africa presents two school systems. Many dysfunctional schools are the ones situated in the townships whilst functional schools are situated in former white areas. Years after the fall of apartheid historically black African schools have failed to attract white learners. Therefore, apartheid influences still loom large in African schools. Spaull (2012) illustrates the two education systems as follows:

Table 1. The two education systems (Spaull, 2012)

\author{
Dysfunctional Schools (75\% of Schools) \\ Weak Accountability \\ Incompetent School Management \\ Weaker Teacher Content knowledge \\ Higher Teacher Absenteeism (1 month/year) \\ Extremely Weak learning: Most Students fail Standardised Tests
}

\author{
Functional Schools ( $25 \%$ of Schools) \\ Strong Accountability \\ Good School Management \\ Adequate Teacher Content Knowledge \\ Low Teacher Absenteeism (2 weeks/year) \\ Adequate Learner performance (Primary and Matric)
}

Children and families, who are trapped in dysfunctional schools as illustrated in Table 1 above, are the weak ones. The families of these children are usually unemployed, unskilled and black. Their schools have no prospects of succeeding given the prevailing circumstances. Moreover, these schools are different from the suburban former white schools that serve middle class families. Below, the focus is on how the children are prepared for the two futures by the dual system of education. Opportunities tend to be different for these children in future. "If we looked at 200 black grade 1 children 12 years ago and then look at them again in matric, according to the 2007 results, only 1 out of the 200 were eligible for a maths or science degree based on their matric marks - the corresponding figure for white children was 15 times higher" (Spaull, 2012).

Poverty can be said to be the main culprit in debilitating the poor children future. Moreover, other education roleplayers including parents, teachers, districts are unable to serve the poor child. Schools in this scenario end up perpetuating the malaise for poor families trapped in dysfunctional schools. Children in poor schools are exposed to conditions that have a negative impact on the growing children. The lack of resources in poor schools is cited as one of the factors that result to poor performance. However, some authors such as Taylor (2008:2) postulates that, "South Africa is outperformed by 8 surrounding countries, many of which, including Mozambique, Kenya, Uganda and Tanzania are much poorer..." Taylor here is showing that many school systems can and do achieve higher quality with far fewer resources. However, it remains a reality that many schools struggle in South Africa in the face of scarce resources. This is complicated in many instances by the lack of commitment from teachers. The quality of teachers is crucial in all schools, more so in poor under-resourced schools with poor families. The teachers in many of these are the only resource in formal education. This implies that many of these children will be as good as their teachers. Taylor (2008:1011) succinctly puts this:

\begin{abstract}
It is evident that what children learn is heavily dependent on what teachers know and do in their classrooms. This is especially true for poor children who get little support for school work from their homes and little intellectual stimulation in their broader social environments. In the words of barber and Mourshed (2007), the quality of an education system cannot exceed the quality of an education system cannot exceed the quality of its teachers, and the only way to improve outcomes is to improve instruction.
\end{abstract}

Yet children in rural areas have ill-prepared teachers. In general, teachers are not as committee as they should be in "failing schools". In a recent study the author visited three schools in a Gauteng township. In each tow visiting teachers from Europe were interviewed (Msila, in preparation). The teachers mentioned aspects that had negative effects on learner outcomes:

- High learners outcomes;

- Bunking classes and setting in the staffroom;

- Lack of direction from school management; and

- The apparent absence of a vision.

The visiting teachers also highlighted the impact of these on the children. They found children who did not have any high self-esteem about themselves. The learners did not know "normal school" hence they did not usually welcome the "new teachers well. They found the children lacking the necessary basics in reading and mathematics. Children in many such schools are short-changed by the system and soon grow to find no value in education. A number of aspects 
add to the negative view of schools. In another recent study a City Press newspaper report by Masondo (2013) cites Spaull's study that found that grade 6 teachers from disadvantaged schools cannot solve basic arithmetic problems. Masondo (2013: 8) quotes Spaull who contends, "One of the most striking features of inequality in South Africa is that the best-performing Grade 6 pupils know more than some Grade 6 teachers albeit their own". In response to this report, the Ministry of Education found it crucial to introduce the Annual National Assessments which is now briefly discussed.

\title{
4. The Annual National Assessment Results
}

ANA is an assessment meted out to more than 6 million primary school children every year. The Department of Basic education uses these results to see what interventions need to be instituted to improve learner performance. Usually the public is more interested in the last class of school referred to as matric or grade 12. However, there has been a gradual realization that good matric results will be attained if the performance is good in the lower grades. In Action Plan to 2014: Towards the Realisation of Schooling 2025 the first three goals relate to outputs in Grades 3, 6 and 9 and are spelt out as follows:

(i) Increase the number of learners in grades 3 who, by the end of the year, have mastered the minimum language and numeracy competencies for Grade 3;

(ii) Increase the number of learners in Grade 6 who, by the end of the year, have mastered the minimum language and mathematics competencies for Grade 6; and

(iii) Increase the number of learners in Grade 9 who, by the end of the year, have mastered the minimum language and mathematics competencies for Grade 9.

(DBE 2012:3)

At the beginning of 2010 nine provincial education departments agreed to test all grade s 1-6 at the end of 2010 . Grades 2-7 pupils were tested on what they had learnt the previous year. The pupils sat for tests in numeracy and literacy in South Africa.

\section{Literacy and Numeracy: South Africa Losing a Race?}

South Africa continues to increase the education budget annually in an endeavour to better the state of education. However, as the ANA results above illustrate, its education is still ranked among the lowest countries. The above ANA results show that there is much that needs to be accomplished in an attempt to improve ECD education. Without the effective primary education children will not be redeemed by formal education. Below, the focus will be on teacher training because other critics find problems in teacher preparation. Madisaotsile (2012) argues that among the challenges that result to poor quality of education in South Africa are dropout rates levels, poor teacher training, unskilled teachers, lack of commitment to teach, poor support for learners at home and a shortage of resources. Whilst it is always argued that children who are strong in literacy and numeracy become strong later as workers. The bleak results illustrate above predict a rather bleak prospects for the young children unless drastic changes are effected.

The plummeting literacy and numeracy results in basic education have implications upon many graduates who are found wanting in literacy as well as numeracy (Simbo, 2012). Furthermore, Simbo (2012:165) points out:

\begin{abstract}
The literacy and numeracy problems in South Africa make one doubt if education institutions that provide basic education appreciate what learners are looking for when they come to school. Learners come to school for an opportunity to receive a certain quality of education that prepares them to proceed successfully through higher education and consequently through life. Any tests that conclude that most South African learners are innumerate and illiterate make one question whether the government and several institutions that provide basic education appreciate that the acquisition of literacy and numeracy skills forms part of acquiring a basic education.
\end{abstract}

Many would argue that although apartheid was outlawed more than two decades ago, it is schools that largely serve black African children that suffer most failures. The latter is the reason why some authors may speak of dual systems in South Africa (Fleisch, 2008; Spaull, 2012). Spaull points out that schools which served predominantly white children under apartheid remain functional while those situated in townships (historically black African areas) have low performers in literacy and numeracy skills. It is of crucial concern that ECD should play a critical role in ensuring the quality of children especially those from black communities. O'Caroll and Hickman (2012) contend that early childhood development centres are vital spaces for nurturing early learning. The challenge though in many situations is the lack of parental involvement in black communities. As O'Caroll and Hickman 2012:16) put it, "parents in disadvantaged communities are also likely to lack confidence, knowledge and skills that can empower them to play a central role in 
supporting their child's literacy and language development."

\section{Mother Tongue Literacy: The Solution?}

South Africa has 12 official languages including the sign langue. Some people argue that learners in schools fail the tests because these are set in either Afrikaans or English both of which were the sole official languages in apartheid South Africa. Therefore, some critics might argue that the key for success is in setting the tests in the pupils' mother tongue. The new curriculum referred to Curriculum Assessment Policy Statements (CAPS) in South Africa seeks to ensure the use of indigenous black African languages. The policy suggests that pupils should learn their mother tongue for the first three years, because research points out that for pupils to learn other languages, they must have a goof foundation in their mother tongue. Yet this policy is opposed by many parents who are non-native speakers of English who perceive English as a language that opens up opportunities for children. The parents are under pressure from society which appears to inform them that there is no place for indigenous languages (Msila, In Preparation). Poor parents whose children attend failing schools also want their children to learn in English. Many indigent parents do not have resources to support their children at home but they still demand that their children be taught in English. Children might be faring badly in the tests because they have to write them in a foreign language.

However, Welch (2012) argues that mother tongue teaching will not solve pedagogical issues. Welch argues that African speaking teachers are not trained to teach mother tongue literacy and that there is no direct teacher training on how to teach beginning reading at all. Therefore, indigenous language teaching is not a panacea and English language has other complexities as well. Welch (2012: 5) also argues:

Many researchers are now pointing to the problem of teacher knowledge. Foundation phase teachers' knowledge of English may not be adequate to build their learners' English skills and even where it is adequate, there has been little preparation for teaching English as a medium of instruction.

These complexities are felt in the actual classrooms as learners fail to understand the basic instructions. For many learners schooling happens at school as there are no books at home or there are no significant others to help the learners read. The latter is Welch's argument when she states that if reading is started only at school then it becomes associated only with formal learning. However, the focus on teacher training by universities will reap benefits in a few years. South African universities have begun supporting foundation phase teaching in indigenous languages. These faculties will empower teachers and this will have an influence on learner achievement.

\section{Teacher Preparation and ECD}

In its endeavours to improve the quality of education in South Africa, the Department of Basic Education has tried to initiate projects that would enhance teacher performance. In 2009 the Teacher Development Summit held in South Africa declared that for the development of a new strengthened, integrated plan for teacher development in the country. Consequently, the Integrated Strategic Planning Framework for Teacher education and Development in South Africa, 2011-2025 was launched. Despite such and similar initiatives, there are still many teachers who need empowerment in South Africa. Whilst it is still difficult to currently quantify the numbers of unqualified and or under qualified teachers, many are teaching with no relevant qualifications. Even those who are qualified need constant in-service training to enhance their skills. The under-preparedness of teachers will always impact on learner success.

Thakrar, Zinn and Wolfenden (2009) argue that we have a challenge of preparing well-prepared and committed teachers in adequate numbers. Furthermore, they point out:

In developing countries this challenge is amplified by significant numbers of un_and underqualified teachers; these teachers urgently need access to professional development level of qualification required for teachers varies, but these standards are generally lower in sub-Saharan Africa than in other regions. Even so only fair countries report all teachers meeting their requirements (UNESCO, 2006). In the Congo and Mozambique less than two thirds of teachers meet the minimum international standard of lower secondary education.

Of course the implications for children at school are very deep. When the teachers are not qualified or competent to teach them the children in school will suffer. This is even more so when the parents do not have the necessary social and cultural capital. The poor child would experience the social reproduction of education because education will fail to redeem them from the vicious cycle. Many children who fail the tests such as ANA do so because among others, they are 
in schools with few resources, no firm management structures, no parental involvement, less district officials' guidance and most importantly, teachers who are not ready to teach. Children who do not have effective teachers will not appreciate being learners because effective teachers model how their pupils should be.

\section{Concluding Comments}

ANA is one aspect that illustrates the effects of poverty on children in formal education. Many at-risk children are poor and black. Leroy and Symes (2001) state that poverty is considered a major at-risk factor. Literature also points out that some of the factors that compound poverty and slow progress of children in school are very young, single or low educational level parents; unemployment; abuse and neglect; substance abuse; dangerous neighbourhoods; homelessness; mobility; and exposure to inadequate or inappropriate educational experiences. The case of South Africa is made peculiar by history. Historically, black African schools still experience many challenges; under-resourced schools, schools with unqualified staff, school with majority working class parents are all situated in the townships. Pupils in these schools suffer and soon they find school a different world from the home environment. Schools tend to speak a different language than that they are used to. They also learn that values at school are different and the child learns to try and internalise values of parents who want to conform the society's set values.

It is clear that there are various role-players who need to be part of the solution in solving early childhood education. The majority of children face problems both from schools and from families. Many parents fail to support schools whilst teachers in schools might highlight the challenges they have as they do not get the necessary support from the parents.

\section{Suggestions of Improving Policy}

\subsection{Making Grade R compulsory in public Schools}

Up to recently, early childhood was a project of private entities. Public schools only start from grade 1 . This means that poor parents, especially those in rural schools do not have any access to ECD institutions. Those situated in historically black African areas are under-resourced and have unqualified staff member. As a result of these education offered in these institutions tends not to be effective. However, recently, August 2013, the Minister of Education has proclaimed that as from 2014 all public schools will offer ECD classes. These pre-grade 1 classes will be crucial in supporting children for a school career of 12 years. The only challenge might be the need to train more specialist teachers for the grade $\mathrm{R}$ classes.

\subsection{Teacher Training at Higher Education Institutions}

One of the aspects that is clear from the discussions above is that paradox of the non-native speakers of English who find that schools do not "talk their languages". This is a paradox because frequently the language complexity is compounded by parents who want their children to learn to speak English from the Grade 1 class. However, currently higher education institutions have introduced programs for pre-service teachers that support the use of indigenous languages. More research shows that learners are failing in tests because the learners are not taught in their mother tongue.

The School Governing Bodies (SGB) are democratically elected bodies to govern schools need to work with parents and show them why the learners in the foundation Phase need to learn in their mother tongue.

\subsection{CAPS Policy}

Linked to the above is the modified curriculum in South Africa. Referred to as Curriculum and assessment Policy Statement, this policy has amended the language policy. This policy concedes that the indigenous languages should be used as the languages of teaching and learning whilst English and other languages are referred to as (First) additional language: 
Table 3: Time allocation - Foundation Phase

$\quad$ Subject
Home language
First Additional Language
Mathematics
Life Skills
Beginning knowledge
Creative Arts
Physical Education
Personal and Social well-being

Grade R (hours)
10
7
6
1
2
2
1

Grade 1-2 (hours)
$7 / 8$
$2 / 3$
7
6
1
2
2
1

Grade 3 (hours)
$7 / 8$
$3 / 4$
7
7
2
2
2
1

\subsection{Teacher Improvement}

As highlighted in earlier arguments, an empowered educator will produce a better learner. There are various initiatives that the government is trying improve teacher quality. One of these is to reopen teacher training colleges whish were closed in the late 1990s immediately after apartheid education was outlawed. The Department of Higher Education and Training intends to reopen these as from 2013. Money has been put aside to enhance teacher quality and institutions. Furthermore, the Department of higher Education and Training seeks to emphasize the development of Foundation Phase teachers especially those who will be able to teach indigenous

Black languages. The South Africa Info Website (2012) reported how the DHET is planning to put aside money to develop lecturers at universities. This website reports:

Meanwhile, an amount of R499 million has been allocated to the country's universities for teaching development grants to help improve graduate outputs, and R194 million for foundation programmes to improve the success rate of students from disadvantaged educational backgrounds.

There has also been a growth in teachers qualifying for teaching. In 2011 for example, 10. 370 newly qualified teachers graduated from universities. The latter is an increase of $75 \%$ since 2008. The Department of Basic Education believes that over 14000 new teachers would have been trained and qualified by the year 2014 (SAGI, 2013). Childhood education will gain if more teachers are prepared well and are effective in their classrooms.

\section{References}

Department of Basic Education (DBE). (2011). South African Country Report: progress on the implementation of the Regional Education and Training Plan (Integrating the second Decade of Education in Africa and protocol on Education and Training. Pretoria: The Author.

Education White Paper 5 on Early Childhood Education. Meeting the Challenge of Early Childhood Development in South Africa. Pretoria, May 2001.

Education for All Global Monitoring Report (EFA GMR). (2013). Addressing the Crisis in early Grade Teaching. Policy Paper 07, April, 17.

Evoh, C.J., \& Mafu, N. (2007). How 'Basic' is Basic Education?: Restructuring Basic Education in Post-apartheid South Africa within the Context of EFA. International Perspectives on Education and Society, 8, 427-451.

Fleisch, B. (2008). Primary Education in Crisis: Why South African Schoolchildren Underachieve. Cape Town: Juta

FPG. (2013). The impact of Early Childhood Teacher Education: How to answer the unanswerable question. FPG Snapshot 68.

Haques, M.N., Nasrin, S., Yesmin, M.M., \& Biswas, M.H.A. (2013). Universal Pre-Primary Education: A Comparative Study. American Journal of Educational Research, 1(1), 31-36.

Masondo, S. (2013) Grade 6 pupils beat teachers at maths. City Press, October 27, 2013, pg. 8.

Msila, V. (In Preparation). "No! Say that in English Sasa!": Black African parents and the language contest in South Africa.

Modisaotsile, B.M. (2012). The failing Standard of Basic Education in South Africa. AISA Policy Brief, 72:1-7.

O'Carroll, S., \& Hickman, R. (2012). Narrowing the Literacy Gap. Wordworks: Cape Town.

OECD. (2013), OECD Economic Survey: South Africa 2013. [Online] Available http://www.dx.doi.org/10.1787/eco_surveys.zaf-2013-en (September, 13, 2013)

SAGI. (2013), Improve the quality of Basic Education and create a skilled and capable Workforce to support an Inclusive growth Path. [Online] Available http://www.info.gov.za/issues/education (August 20, 2013)

Simbo, C. (2012). Defining the term Basic Education in the South African Constitution: An International Law Approach. Law, Democracy 
\& Development, 16: 162.

SouthAfrica.Info. (2012), South Africa to reopen teacher training colleges. [Online] Available http:www.southafrica.info/about leducation/teachers (October 18, 2013)

Spaull, N. (2012). Poverty \& Privilege: primary School Inequality in South Africa. Stellenbosch Economic Working papers: 13/12, July, 123.

Strickland, D. and Riley-Ayers, S. (2006). Early Literacy: Policy and Practice in the Preschool Years. NIEER.

Taguma, M., Litjens, I. and Makowiecki, K. (2013). Quality Matters in early Childhood Education and Care. Helsinki: OECD.

Taylor, N. (2008). What's wrong with South African Schools? Presentation to the Conference - What's Working in School Development. Johannesburg, JET Education Services, February 28-29, 2008.

Taylor, N., Fleisch, B., and Shindler, J. (2007). Education Scenarios for 2019. Paper prepared for the Key Driving Forces Scenarios 2019. Johannesburg, The Office of the Presidency, June 11-12, 2007.

Thakrar, J., Zinn, D., and Wolfenden, F. (2009). Harnessing Open Educational Resources to the Challenges of Teacher Education in Sub-Saharan Africa. The International Review of Research in Open and Distance Learning, 10(4).

The Consultative Group on Early Childhood Care and Development. (2013). The Importance of Early Childhood Development Education. Dakar: The Author.

Unterhalter, E. (2013). Education Targets, Indicators and Post-2015 Development Agenda: Education for All, the AMGs, and Human Development. Working Paper Series.

Welch, T. (2012). Why mother tongue literacy isn't working: Policy, Pedagogy, Parents and Publishing. Guest Address at the Annual General Meeting of the Witwatersrand Council on Education. Wits School of Education, Johannesburg. October 9, 2012. 